STATE OF ALASKA

DEPARTMENTT OF NATURAL RESOURCES

DIVISION OF GEOLOGICAL AND GEOPHYSICAL SURVEYS

Btll Shotfleld, Govemor

Euher C. Punateke, Commlesioner

Pedro Denton, Director

September 1986

Report of Investigations 86-24

GROUND-WATER CONTAMINATION AT PETERS CREEK, MUNICIPALITY OF ANCHORAGE, ALASKA: GROUND-WATER OCCURRENCE AND MOVEMENT

By

James A. Munter

In cooperation with Alaska Department of Environmental Conservation 
STATE OF ALASKA

Department of Natural Resources

DIVISION OF GEOLOGICAL \& GEOPHYSICAL SURUEYS

According to Alaska Stature 41, the Alaska Division of Geologlcal and Geophysical Surveys is charged with conducting 'geologtcal and geophysical surveys to decermine the potential of Alaskan land for production of metals, minerals, fuels, and geothermal resources; the locations and supplies of ground water and construction materlals; the potential geologic hazards to bufldings, roads, bridges, and other instaliations and structures; and shall conduct such other surveys and Investigations as will advance knowledge of the geology of Alaska.'

In addition, the Division of Geological and Geophysical Surveys shall collect, record, evaluate, and distrtbute data on the quantity, quality, and location of underground, surface, and coastal water of the state; publish or have published data on the water of the state and require that the results and findings of surveys of water quality, quantity, and locacion be filed; require that waterwell concractors flle basic water and aquifer data, Including but not ilmited to well location, estimated elevation, welldriller's logs, pumping tests, flow measurements, and water-quality determinations; accept and spend funds for the purposes of this section, AS 41.08 .017 and 41.08 .035 , and enter into agreements with individuals, public or private agencles, communteles, private industry, and state and federal agencles; collect, record, evaluate, archıve, and distribute data on seismic events and engtneerting geology of the state; and identify and inform public officials and industry about potential selsmic hazards that might affect development in the state.

DGGS offices are located at:

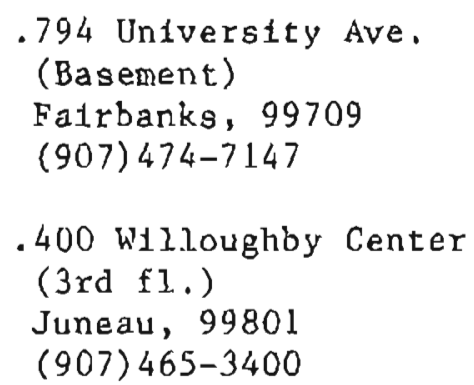

$.3601 \mathrm{C} \mathrm{St} .(8 \mathrm{th} \mathrm{fl.})$

P.O Box 7028

Anchorage, 99510

(907) 561-2020

- F1sh Hatchery Road

P.O. Box 772216

Eagle River, 99577

(907) 688-3555

This report is for saIe by DGGS for $\$ 2$. UGGS publications may be inspected at the following locations. Ma11 orders should be addressed to the Fairbanks office.

\author{
.794 University Ave. \\ (Basement) \\ FaIrbanks, 99709 \\ .3601 C St. (8th fl.) \\ P.0. Box 7028 \\ Anchorage, 99510
.400 Willoughby Center
( 4 โh fl.) \\ Juneau, 99801
}




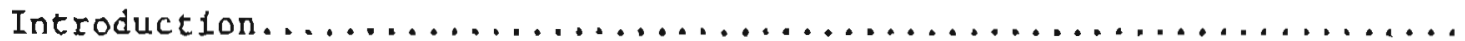

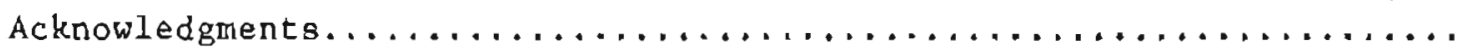

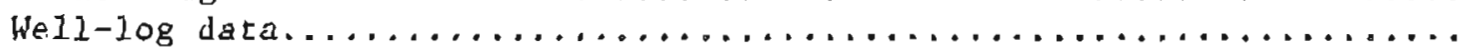

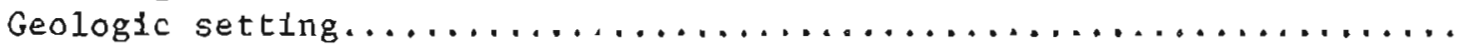

Major confined aquifers.............................

Ski Road aquifer...............................

Peters Creek aquifer............................

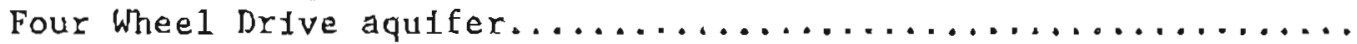

Oberg Field aquifer..............................

Observed pattern of ground-water contamination.............

Conclusions. ...................................

References cited.

\section{FIGURES}

Figure 1. Location of the Peters Creek study area............... 2

2. Location of contaminated wells at Peters Creek........... 3

3. Structure contour map of the bedrock surface............ 5

4. Isopach map of Quaternary sediments.................. 6

5. Structure contour map of the top of major confined aquifers at Peters creek..................... 7

6. Potent1ometric surfaces of major confined aquifers at Peters Creek............................. 8

7. Hydrogeologic cross section showing subsurface conditions near the contaminated area....................

TABLE

Table 1. Maximum levels of benzene concentration determined from water drawn from Peters Creek wells from April through

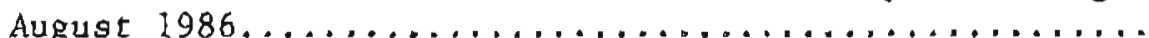




\title{
GROUND-WATER CONTAMINATION AT PETERS CREEK, MUNICIPAIITY OF ANCHORAGE, ALASKA: GROUND-WATER OCCURRENCE AND MOVEMENT
}

\author{
By James A. Munter ${ }^{1}$
}

INTRODUCTION

During April through August 1986, 15 private domestlc wells at Peters Creek, Municipality of Anchorage, Alaska (f1gs. l and 2), were found to be contaminated with a variety of aromatic hydrocarbons, Including benzene, toluene, and xylene (Alaska Department of Environmental Conservation, written commun., 1986). As of August 1986, the source of contamination was unknown. A hydrogeologic investigation was conducted to provide a framework for further work to discover the source and evaluate movement of the contaminant plume. This report summartzes data collected and analyzed through August 1986 pertinent to the occurrence and movement of ground water and assoctated contaminants at Peters Creek.

\section{ACKNOWLEDGMENTS}

James $F$. Hayden and other staff members of the Alaska Department of Environmental Conservation (ADEC) collected much of the data described hereln and provided useful consultation; area well drillers produced many useful wel1 logs. Randa11 G. Updike of the Alaska Division of Geological and Geophysical Surveys and Gordon Nelsor of the U.S. Geological Survey (USGS) provided helpful reviews of the manuscript.

\section{WELL-LOG DATA}

The analyses presented in this report are based largely on information obtained from logs of water wells drilled in the Peters Creek area. Well logs typically consist of drillers' descriptions of geologic materials encountered during driling and well-construction data such as casing diameter, well depth, and type and depth of well opening. During Apr11 and May 1986, water levels were measured in numerous wells (Dowl Englneers, 1986), Including some for which no well logs are available. The plotted locations of most wells shown in this report are approximate because exact locations of wells on most lots are not known. Some wells were plotted in the middle of the fourth-order allquor parcel of a section (2.5-acre area).

\section{GEOLOGIC SETTING}

The Peters Creek study area is located at the western edge of the Chugach Mountains of southcentral Alaska, about 2 mi frou Knik Arm (fIg. 1). The Chugach Mountains near Peters Creek are composed of merasedimentary, metavolcanic, and plutonic rocks of Jurassic to Cretaceous age (Brunett and Lee, 1983) The Kenal Group (Tertlary) conststs of siltgtone, sandstone, and coal (Zenone and others, 1974) and occurs throughout much of the lowlands near

lAlaska Division of Geological and Geophysical Surveys, P.0. Box 772116 , Eagle River, Alaska 99577. 


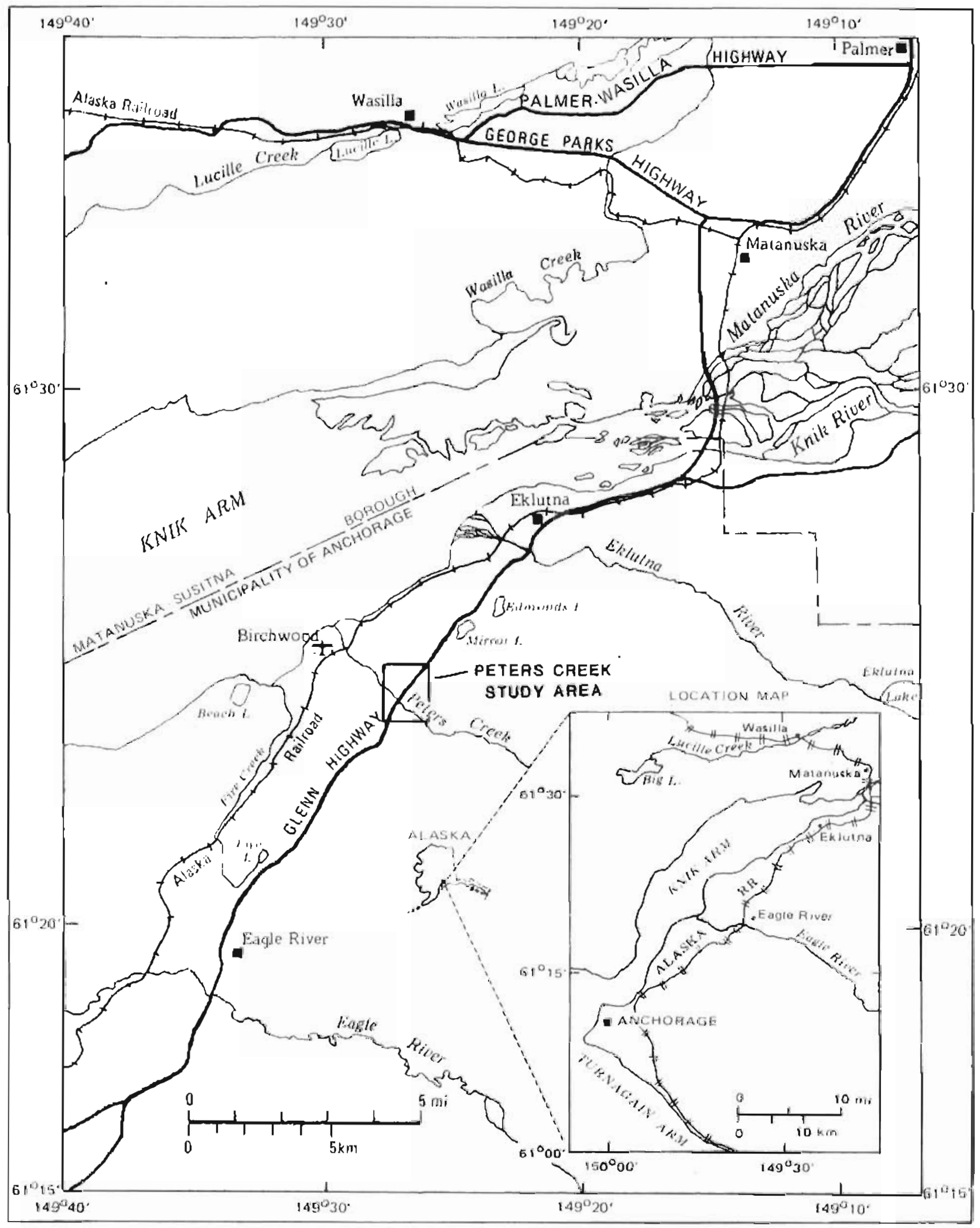

Figure 1. Location of the Peters Creek study area. 


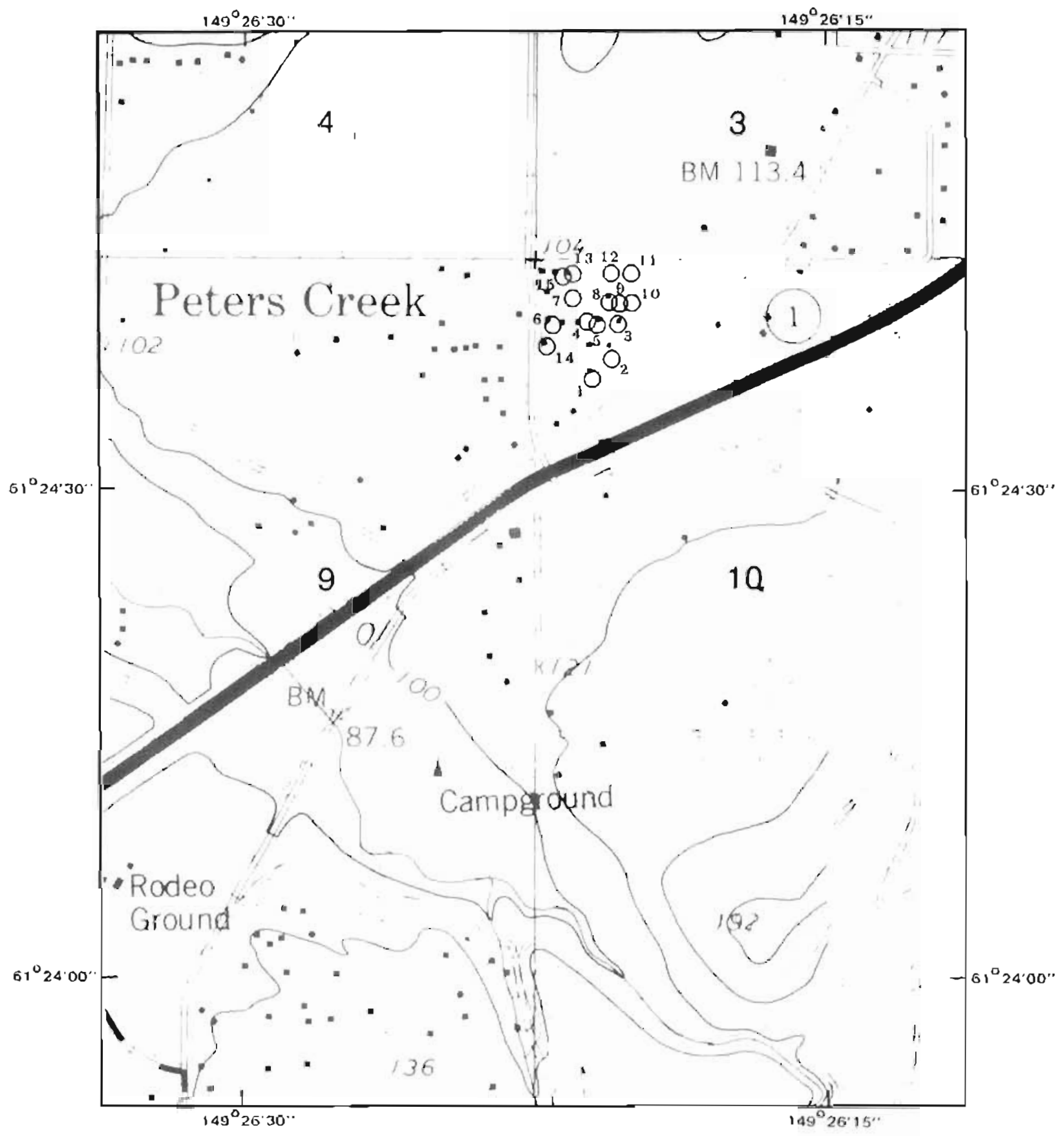

Base from U.S. Geological Survey Anchorage B-7 NE and NW Quadrangles, Alaska, 1979.

Tho siudy area is located within T, $15 \mathrm{~N}$. and $A .1$ W., Seward Meridian

CONTOUR INTERVALS 5 AND 20 METEPS

\section{EXPLANATION}

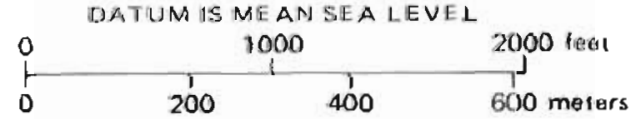

Locations of wells that contain

2 benzene-conraminaled water. isee table 1).

Figure 2. Locacton of contaminaced wells at Peters Creek. 
Peters Creek; it is overlain by a mantie of nonlithlfied glacial deposits of Quaternary age. Because the contact between rocks of Tertiary and preTertiary age is obscured by glacial drift and because no wells are known to penetrate Kena1 Group rocks in the study area, it is not known whether Kena1 Group rocks underlie the study area. The term bedrock is used in this report to refer to rocks of Tertiary and pre-Tertiary age in the Peters Creek area.

A structure contour map of the bedrock surface, based on we11-log and avallable outcrop data (Zenone and others, 1974), is shown in figure 3 . At approximately the section line that separates secs, 9 and $10, T, 15 \mathrm{~N}$., R. I W. the elevation of the bedrock surface drops sharply west compared to the relatively flat bedrock surface to the east. ThIs subsurface escarpment is not evident from surface topographic features, but may be associated with the contact between rocks of Tertiary and pre-Tertiary age.

Geologic deposits near the land surface are primarily nonlithlfied glacial and glaclofluvial deposits of Quaternary age with minor alluvial and colluvial deposits near Peters Creek (Zenone and others, 1974). The total thickness of nonlithified deposits ( $E 1 \mathrm{~g}$. 4) is derived from contour maps of the bedrock surface and land surface ( $f j g .3$ ). The thickening of Quaternary deposits that occurs in section 9 primarily results fron the escarpment on the bedrock surface.

\section{MAJOR CONFINED AQUIFERS}

Most wells at Peters Creek obtain water from glaciofluvial aquifers composed princlpally of sand and gravel that are confined by silty glacial sediments, predominantly till. Figure 5 shows the locations of four major confined aquifers and the structure contours of the top of each aquifer; figure 6 shows the potentiometrlc surfaces of the aquifers. The potentiometric surface of an aquifer is the level to whlch water rises in 8 well that taps the aquifer. Figure 7 is a hydrogeologic cross section that depicts subsurface conditions near the contaminated area.

\section{Sk1 Road Aquifer}

The Ski Road aquifer occurs in most of the eastern half of the study area and is tapped by at least 32 wells. Most wells penetrate the aquifer only a few feet and have reported ylelds of 5 to 25 gallons per minute (gpm). Well yields as high as $100 \mathrm{gpm}$ have been reported, and the aquifer may be up to $100 \mathrm{ft}$ thick. The potentiometric surface of the aquifer (fig. 6) shows that ground water in the aqufeer moves princlpaliy from east to west.

\section{Peters Creek Aquifer}

The Peters Creek aquifer covers an area of about 15 acres and 15 tapped by at least 19 wells. A11 15 of the benzene-contaminated wells in the area obtaln water from the Peters Creek aquifer or are located adjacent to the aquifer and obtain water from the bedrock aquifer. The Peters Creek aquifer is relatively thin (reported thicknesses vary from 1 to $20 \mathrm{ft}$ ) and unproductive (reported yleids range from 2 to $15 \mathrm{gpm}$ ). The potentiometric surface of the aquifer ( $f 1 \mathrm{~g}, 6$ ) shows that ground water moves princlpally from east to west through the aquifer. 


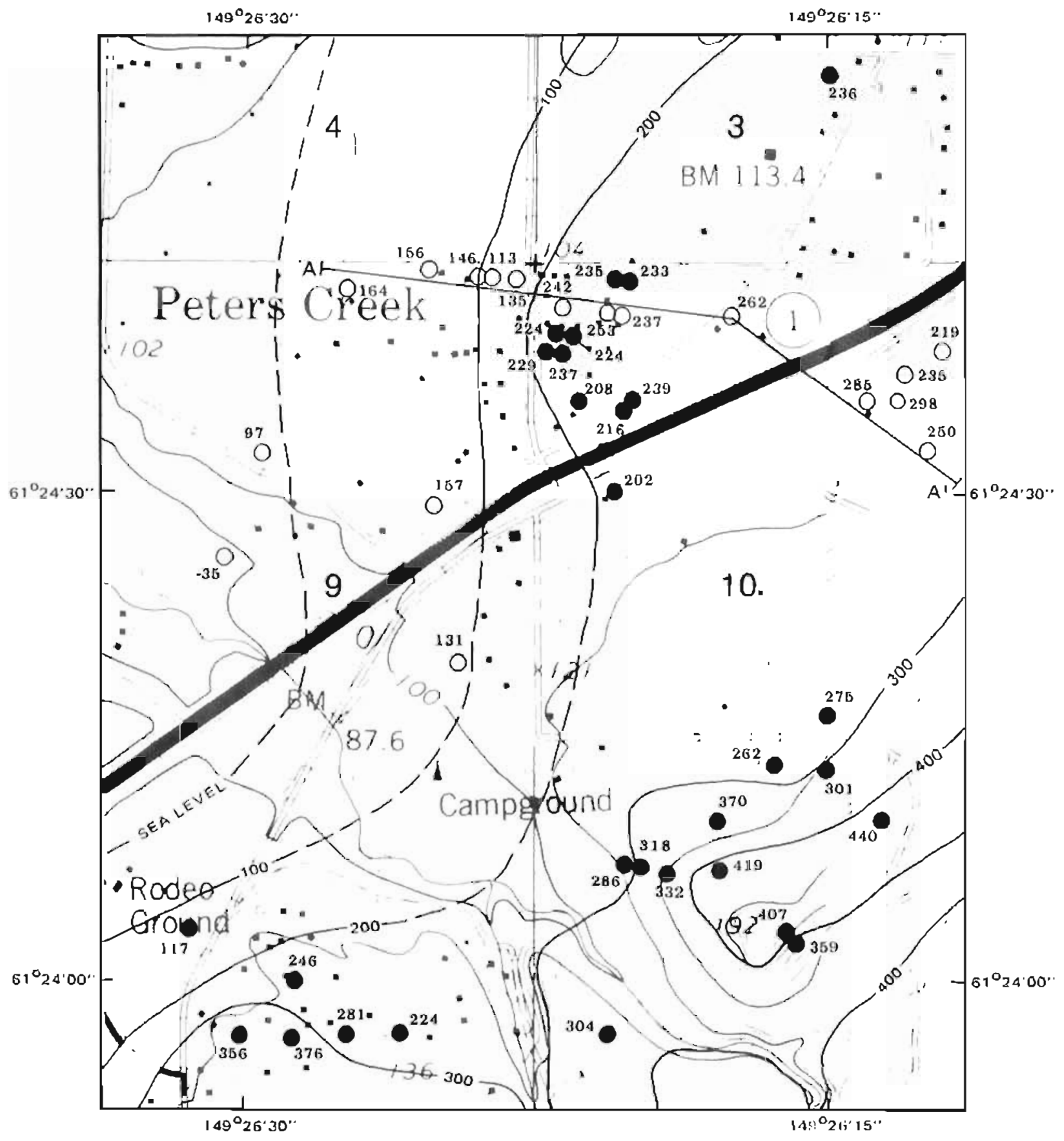

Base trom U.S. Geological Survey Anchorage B-7 NF ancl NW Ousdrangles, Alaska, 1979.

The study area is located willin T. $15 \mathrm{~N}$ and R. I W., Seward Mier Idian

\section{EXPLANATION}

286 Locittion of well thal penetrates bedrock and - 100- Line of equal plevation of bedrock surlace.

- elevation of bedrock surface (ft) Contour interval 100 leet, line dashed where approximata.

97 Location of well that does not penetrate

bedrock and elevation of bollom of woll (fi) $A \longmapsto A^{\prime}$ Cross sectlon (see hig. 7)

CONTOUR INTERVALS 5 AND 20 METERS

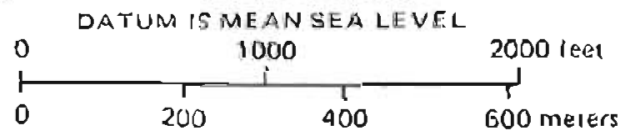

Figure 3. Structure contour map of the bedrock surface. 


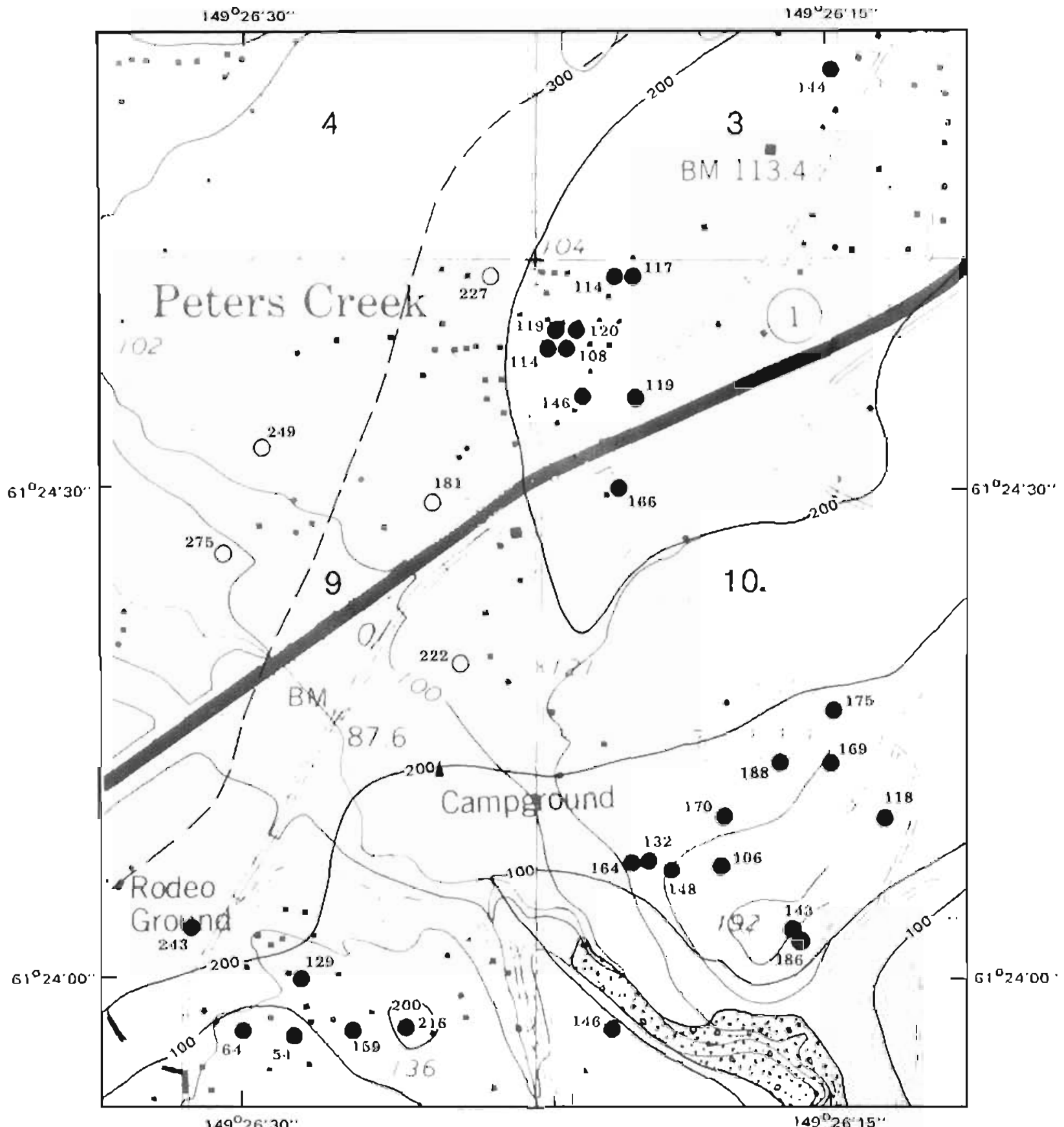

Base from U.S. Geological Survey Anchorage

B-7 NE and NW Quadrangles, Nlaskis, 1979.

\section{EXPLANATION}

11.4 Location of well that penetrates becirock and -100-

- thickness of nonlithltied deposits (fi)

Line of equal thickness of nonlixhufied ma

The siudv area is located within T. $15 \mathrm{~N}$. and $R .1$ W., Sewaru Meridian dashed where approximate.

$2+45$ Location of well that does not penetrate

$O$ bedrock and depth of well (it)

[:- Area where bedrock is al or near the land

CONTOUR INTERVALS 5 AND 20 METERS

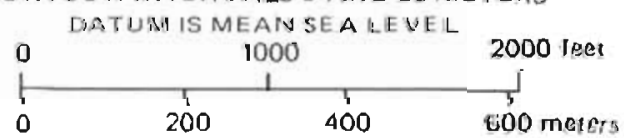

Figure 4. Isopach alap of Quacernary sediments. 


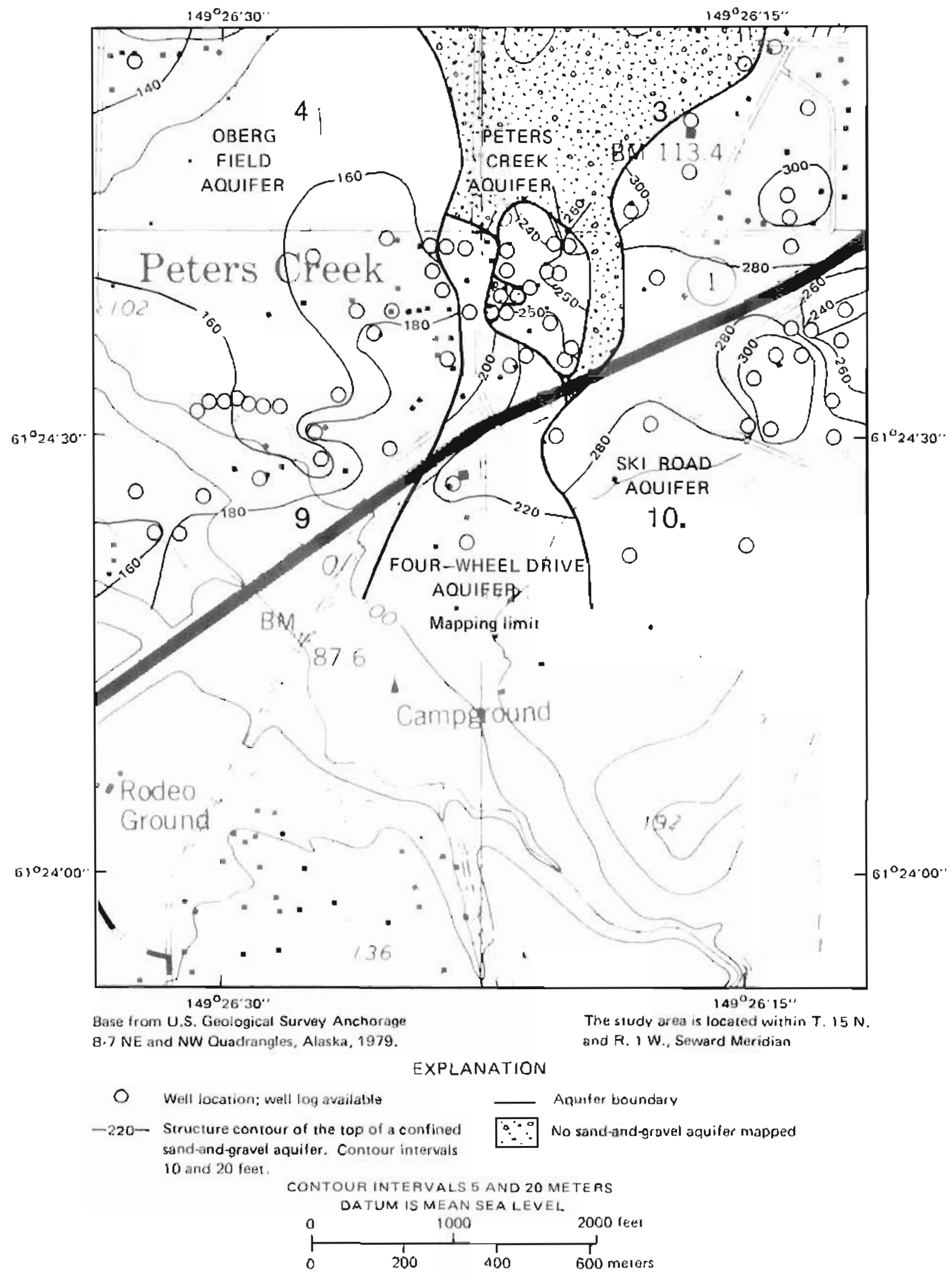

Figure 5. Structure contour map of the top of mafor confined aquifers at Peters Creek. 


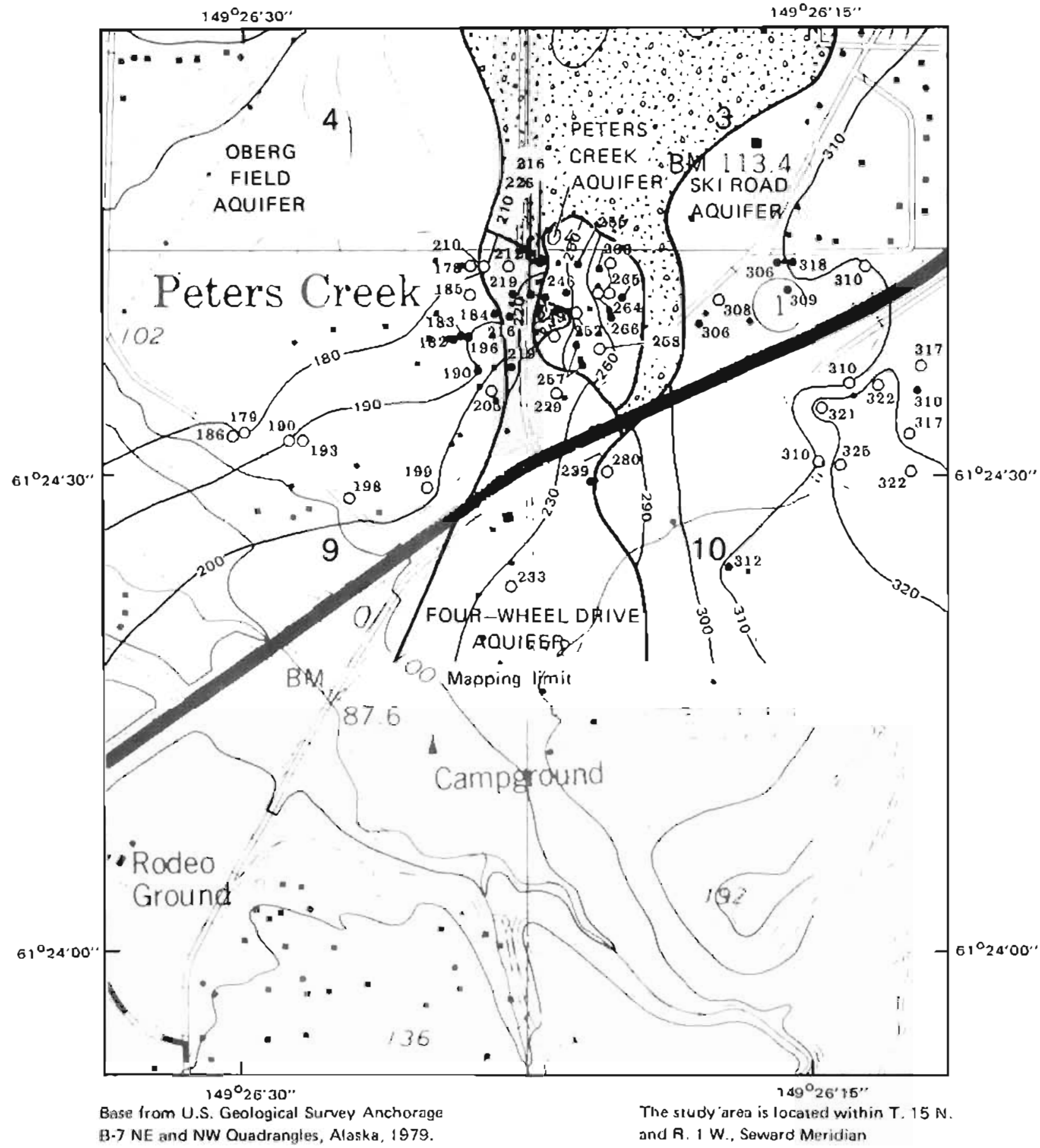
B.7 NE and NW Ouadrangles, Alaska, 1979.

EXPLANATION

Elovation (it) ni water level messured during April-May 1986 (DOWL Engineers, 1986)

3120 Woll location; woll log svailable

198 Well locotion; no well log available

- Aquilor boundary

$\because \because \quad$ No sand-and-gravel aquiler mapped
-200- Polentiometric contour, April-Mav 1986. Contour interval 10 foet

CONTOUK INTERVALS 5 AND 20 METERS JA IUM IS MEAN SEA LEVEL

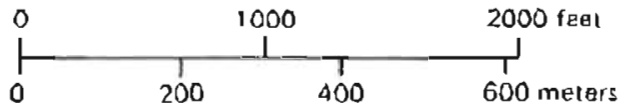

Figure 6. Potentlometric surfaces of major confined aquifers at Peters Creek. 


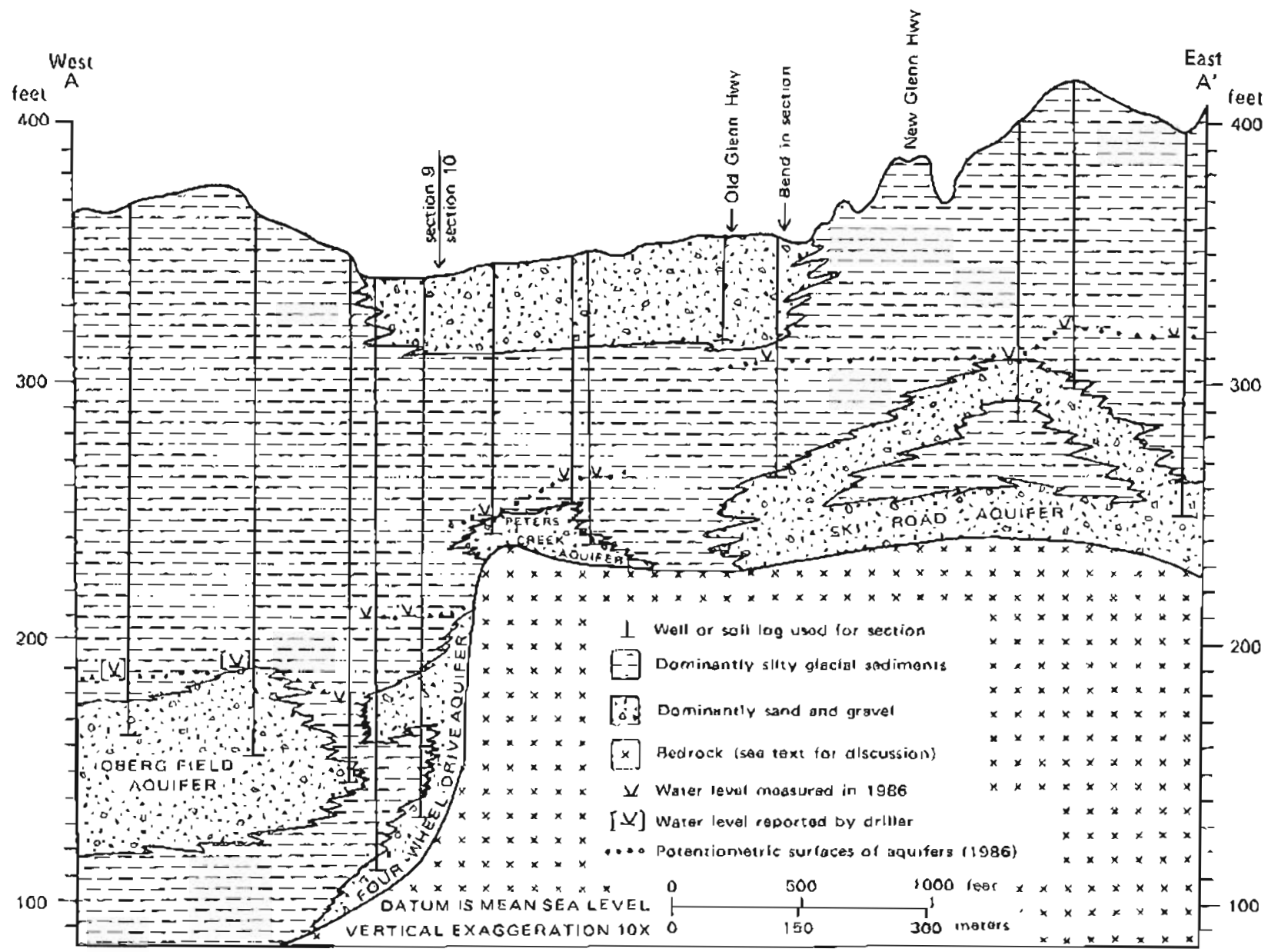

Figure 7. Hydrogeologic cross section showing surburface conditions near the contaminated area.

Four Wheel Drive Aquifer

The Four Wheel Drive aquifer accurs Imedlately west of the Peters Creek and Sk1 Road aquifers and has an elongated north-south orientation. The aquifer overlfes an ares where the bedrock surface slopes downward relatively steeply to the west. Avallable well-log data, although sparse, suggest that the aquifer 1 s composed of multiple sand and gravel bodies that are complexly interconnected. Reported yields of wells that tap the aquifer range from 3 to $13 \mathrm{gpm}$, and avallable water-level data show that ground water moves princlpalIy from southeast to northwest (fig. 6).

\section{Oberg Field Aquifer}

The Oberg Field aquifer is a productive aquifer tapped by at least 30 wells in the west half of the study area, including two wells used to supply 
water to a temporary pubilc water system that serves the area of contaminated ground watex. A public well that serves Northwoods subdivision is located about $0.67 \mathrm{mi}$ northwest of the contaminated ground warer and probably also taps the Oberg Field aquifer.

The top of the Oberg Fleld aquifer occurs at a depth of 160 to $200 \mathrm{ft}$ in most of the study area. Although no wells are known to fully penetrate the aquifer, its thickness may be $100 \mathrm{ft}$ in some areas. Most reported well yields range from 10 to $50 \mathrm{gpm}$, but ylelds of up to $200 \mathrm{gpm}$ have been reported. A test of the Oberg Field aquifer (Munter, 1986) confirmed that the aquifer is relatively productive. Ground-water flow within the oberg Field aquifer is generally from the soucheast towards the northwest in the study area.

A hydrogeologic cross section ( $E 1 g$. 7) through the area of contaminated ground water shows that ground water generaliy moves from the land surface down to the confined aquifers and from east or southeast to west or northwest through the serles of aquifers. Ground-water gradients within the aquifers are typically less steep than gradients between aquifers, which is consistent with the inferred permeability contrasts between aquifer sands and gravels and silty confining-unit lithologles. Because specific hydraulic characteristics of the aquifers and confining units are largely unknown, meaningful ground-water flow velocities cannot be estimated.

Avallable well and soll-borlng logs (DOWL Englneers, 1986) show that the near-surface alluvium shown in figure 7 is composed of a vartety of sediment types, including slits, sands, and gravels, and may be locally or seasonally water-bearing. Permeable sands and gravels within this untt may have slgnificant potential for lateral migration of contaminants under water-table condtions.

\section{Observed Pattern of Ground-water Contanination}

Table 1 lists the maximum levels of benzene contamination observed from April through August 1986 in wells at Peters Creek (ADEC, wrttten comoun., 1986). Although consistent sampling methods were not used at all wells (J.F. Hayden, ADEC, oral commun, 1986), the benzene-concentration data are useful indicators of the extent and intensity of the contaminant plume because their values span four orders of magnitude. The highest values are for wells In the eastcentral part of the plume ( $f 1 g$. 2) with decreasing values to the north, west, and south. Most wells that tap the Peters Creek aquifer are contaminated, which suggests that substantial contaminant migration may have occurred within the aquifer since the contamination was initially discovered in March and April 1986 (Bennett, 1986).

Although collected data cover a short period of time, a review of contaminant-concentration data (ADEC, written commun., 1986) suggests that contaminant levels were increasing, and contamination was spreading within the Peters Creek aquifer through August 1986. This indicates that wells that are currently not known to be contamlnated, yet tap the Peters Creek aquifer, are at a high risk of becoming contaminated. 

Table 1. Maximum levels of benzene con- centrations determined from water drawn from Peters Creek we 11 s from April through August 1986. (See fig. 1 for well locations.)

\begin{tabular}{cc} 
We11 & $\begin{array}{c}\text { Benzene } \\
\text { concentration } \\
(\text { (mg/1) }\end{array}$ \\
\cline { 2 - 2 } 1 & 1.6 \\
2 & 9.1 \\
3 & 40 \\
4 & 9.0 \\
5 & 0.81 \\
6 & 0.051 \\
7 & 3.4 \\
8 & 35 \\
9 & 25 \\
10 & 9.1 \\
11 & 0.081 \\
12 & 5.7 \\
13 & 0.0026 \\
14 & 0.002 \\
15 & 5.2
\end{tabular}

CONCLUSIONS

Four major confined sand and gravel aquifers at Peters Creek, Alaska, have been ddentifled and mapped. The aquifers are confined by tens of feet of silty glactal sediments ( $t 111$ ). Near-surface alluvial deposits may constitute a signiflcant local or seasonal aquifer. Extensive contamination of the Peters Creek confined aquifer by benzene, toluene, and xylene has occurred, but contamination is not known to have spread to the other confined aquifers (as of August 1986). Contamination of the Peters Creek aquifer through August 1986 appears to be 1ncreasing in extent and intensity. Because the source of contamination is unknown, a specific migration path(s) of contamination is unknown. The natural direction of ground-water flow is toward the Four WheeI Drive and Oberg Fleld aquifers, which are used for water supply. Leakage of contaminated water from the Peters Creek aquifer to the Four Wheel Drive or Oberg Fleld aquifers could contaminate these aquifers.

\section{REFERENCES CJTED}

Bennett, Ed, 1986, Peters Creek well tests show petro pollution: Chugiak Eagle River Star, v. 16, no. 17, p. 1.

Brunett, Jilann, and Lee, Mtchael, 1983, Hydrogeology for land-use planning: Peters Creek area, Municlpality of Anchorage, Alaska: U.S. Geological Survey Water Resources Investigations 82-4120, scale $1: 25,000$, 6 sheets.

Dowl Engineers, 1986, Peters Creek private well contamination study: Anchorage, unpublished report prepared for the Alaska Department of Environmental Conservation, unpaginated. 
Munter, J.A., 1986, Results of an aquifer test at Peters Creek, Municipality of Anchorage, Alaska: Talrbanks, Alaska Division of Geological and Geophysical Surveys Public-data File 86-77, $7 \mathrm{p}$.

Zenone, Chester, Schmol1, H.R., and Dobrovolny, Ernest, 1974, Geology and ground water for land-use planning in the Eagle River - Chugiak area, Alaska: U.S. Geologlcal Survey Open-file Report 74-57, 25 p. 